\title{
An uncommon case of apical dentoalveolar abscess of sinusal origin
}

Um caso incomum de abscesso dentoalveolar apical de origem sinusal

Un caso incomum de absceso dentoalveolar apical de origen sinusal

Lívia Natália Sales BRITO ${ }^{1}$

Hellen Bandeira de Pontes SANTOS ${ }^{2}$

Nicássio Silva MENEZES ${ }^{3}$

Marcos Alexandre da Franca PEREIRA ${ }^{3}$

Roseana de Almeida FREITAS ${ }^{2}$

Gustavo Pina GODOY ${ }^{4}$

${ }^{1}$ Departamento de Prótese e Cirurgia Facial, UFPE - Universidade Federal de Pernambuco, 50670-901, Recife - PE, Brasil

${ }^{2}$ Departamento de Patologia Oral, UFRN - Universidade Federal do Rio Grande do Norte, 59056-000, Natal - RN, Brasil

${ }^{3}$ Departamento de Medicina, FAMENE -Faculdade de Medicina Nova Esperança, 58067-695, João Pessoa - PB, Brasil

${ }^{46}$ Departamento de Patologia, UFPE - Universidade Federal de Pernambuco,50670-901, Recife - PE, Brasil

\begin{abstract}
Introduction: Apical dentoalveolar abscesses associated with sinusitis are very uncommon and may expose patients to unfavorable outcomes. Case-report: A 25-year-old female patient sought medical care due to severe, recurrent, long-term frontal facial pain and symptom relief through analgesics. A tomographic examination of the skull did not identify any pathological cerebral alterations. It did, however, evidence diffuse and irregular mucous thickening of all nasal cavities. The patient was referred to an otorhinolaryngologist, who diagnosed the condition as bilateral chronic inflammatory rhinosinusopathy. A rhinoscopy was performed and antibiotic associated with corticoid was prescribed. After the procedure, sinus infection diffusion to the dental tissues was observed, and the patient required emergency dental care due to diffuse facial cellulitis and swelling associated to tooth 26. Due to the absence of clinical signs indicative of carious infection, the condition was diagnosed as an uncommon case of acute dentoalveolar abscess of sinusal origin. After endodontic access for initial drainage, chemical-mechanical preparation of the root canals was performed, in two sessions. After 30 days, a tomography of the sinuses was performed, and results indicated a significant improvement of the infectious process. Due to the rarity of the case presented herein, it is of significant importance to understand the clinical, radiographic and protocol aspects of the case, in order to attend similar cases, as well as the joint action of the dental surgeon and the otorhinolaryngologist for rhinogenic and odontogenic infection management.
\end{abstract}

Descriptors: Otolaryngology; Endodontics; Diagnosis.

\section{Resumo}

Introdução: O abscesso dento-alveolar apical associado à sinusite é muito incomum e pode expor o paciente a um desfecho desfavorável. Relato de caso: Paciente do sexo feminino, 25 anos, procurou atendimento médico devido dor facial frontal de forte intensidade, recorrente, de longa duração e alívio da sintomatologia através de analgésicos. O exame tomográfico do crânio não identificou alterações patológicas cerebrais, contudo, evidenciou espessamento mucoso difuso e irregular de todas as cavidades nasais. A paciente foi encaminhada para otorrinolaringologista que diagnosticou como rinossinusopatia inflamatória crônica bilateral. Foi prescrito antibiótico associado a corticoide e realização de rinoscopia. Após o procedimento houve difusão da infecção sinusal para os tecidos dentários e a paciente necessitou de atendimento odontológico emergencial devido a celulite facial difusa e tumefação associada ao dente 26. Devido à ausência de sinais clínicos indicativos de infecção cariosa, diagnosticou-se como um incomum caso de abcesso dento-alveolar agudo de origem sinusal. Após acesso endodôntico para drenagem inicial realizou-se preparo químico-mecânico dos canais radiculares em duas sessões. Após 30 dias, foi realizada tomografia dos seios da face, exibindo melhora significativa do processo infeccioso. Conclusão: Devido a raridade do caso, torna-se de grande importância o conhecimento dos aspectos clínicos, radiográficos e determinação de protocolos para atendimento de casos semelhantes, assim como a ação conjunta do cirurgião-dentista e do otorrinolaringologista para o manejo de infecções rinogênicas e odontogênicas.

Descritores: Otorrinolaringologia; Endodontia; Diagnóstico.

\section{Resumen}

Introducción: El absceso dento-alveolar apical asociado a la sinusitis es muy inusual y puede exponer al paciente a un desenlace desfavorable. Relato de caso: Paciente del sexo femenino, 25 años, buscó atención médica debido dolor facial frontal de fuerte intensidad, recurrente, de larga duración y alivio de la sintomatología a través de analgésicos. El examen tomográfico del cráneo no identificó alteraciones patológicas cerebrales, sin embargo, evidenció espesamiento mucoso difuso e irregular de todas las cavidades nasales. La paciente fue encaminada a otorrinolaringólogo que diagnosticó como rinosinusopatía inflamatoria crónica bilateral. Se ha prescrito antibiótico asociado a la corticoides y la realización de la rinoscopia. Después del procedimiento hubo difusión de la infección sinusal hacia los tejidos dentales y la paciente necesitó atención odontológica de emergencia debido a celulitis facial difusa y tumefacción asociada al diente 26. Debido a la ausencia de signos clínicos indicativos de infección cariosa, se diagnosticó como un inusual caso de absceso dento-alveolar agudo de origen sinusal. Después del acceso endodóntico para drenaje inicial se realizó la preparación químico-mecánica de los canales radiculares en dos sesiones. Después de 30 días, se realizó la tomografía de los senos de la cara, mostrando una mejora significativa del proceso infeccioso. Conclusión: Debido a la rareza del caso, se vuelve de gran importancia el conocimiento de los aspectos clínicos, radiográficos y determinación de protocolos para atención de casos semejantes, así como la acción conjunta del cirujano-dentista y del otorrinolaringólogo para el manejo de infecciones rinogénicas y odontogénicas.

Descriptores: Otorrinolaringología; Endodoncia; Diagnóstico.

INTRODUCTION

The diagnosis of diffuse pain in the posterior maxilla region can be considered a clinical challenge, since an intimate relationship is observed between the roots of the upper posterior teeth and the floor of the maxillary sinuses and the common vascularization of the sinusal mucosa and periodontal tissue ${ }^{1-3}$. Maxillary sinus diseases are quite common and may be related to inflammatory, infectious, congenital, neoplastic, iatrogenic processes ${ }^{4}$. Inflammatory sinusitis (acute and chronic) of rhinogenic origin are noteworthy 
among these processes. In the acute condition, fluid and liquid levels within the maxillary sinuses are isolated, while in chronic conditions thickening of the maxillary sinuses walls is evident ${ }^{4,5}$. However, sinus infections of odontogenic origin account for $10 \%$ to $40 \%$ of sinusitis cases ${ }^{4,6}$. Thus, the diagnosis and differentiation of these pathologies is of fundamental importance, since the determination of the origin of the maxillary sinusitis is required for treatment success ${ }^{2,4,7}$. In addition, maxillary sinusitis of odontogenic origin differs from rhinogenic sinusitis in their physiopathology, microbiology and treatment 4 .

No significant differences between odontogenic sinusitis and symptoms of other types of sinusitis are noted ${ }^{8}$. In this context, the use of complementary exams becomes essential. Computed tomography (CT) has been described as an effective method to evaluate pathologies and determine the etiology of maxillary sinusitis ${ }^{1,2,3,4,9}$.

Several studies have reported the common dissemination of odontogenic infection through the sinus pathway $2,3,6,7,10-12$. However, reports of rhinogenic sinus infections with root canal odontological dissemination have not been described in the literature. Thus, this study aimed to report an unusual case of apical dentoalveolar abscess of sinus origin, addressing clinical, imaging, differential and therapeutical characteristics.

CLINICAL CASE

A 25-year-old female patient sought care with a neurologist, reporting severe facial pain with daily recurrence. During anamnesis, the patient reported a previous diagnosis of migraine with frequent pain episodes, beginning about 5 months prior to the consultation, intensifying in the previous 7 days. The pain gradually increased, characterized as continuous and of long duration. The patient also reported a slight decrease of the symptomatology with the use of analgesics. A tomographic examination of the skull was requested, which did not indicate any pathological changes in the brain. However, diffuse and irregular mucosal thickening of all nasal cavities was evidenced, indicating chronic inflammatory pansinusopathy (Figure 1A-B). The patient was referred to an otorhinolaryngologist.

Upon physical examination by the otorhinolaryngologist, palpation showed signs of paranasal sinus inflammation, accompanied by painful symptoms. A rhinoscopy evidenced the presence of a purulent obstruction in the anterior nasal region. Based on the clinical assessment and imaging, the patient was diagnosed with chronic rhinosinusopathy, and prescribed levofloxacin (750 mg, oral, once daily for 10 days) and a dose of Diprospan (1 $\mathrm{mL}$, intramuscular). However, during the following day, the patient presented an edema on the left side of the face and pain in the upper arch when performing masticatory movements. After re-evaluation of the tomographic sections, the root of tooth 26 was observed to be intimately connected to the isodense area corresponding to the infectious process in the left maxillary sinus. Thus, the patient was referred to a dental evaluation.

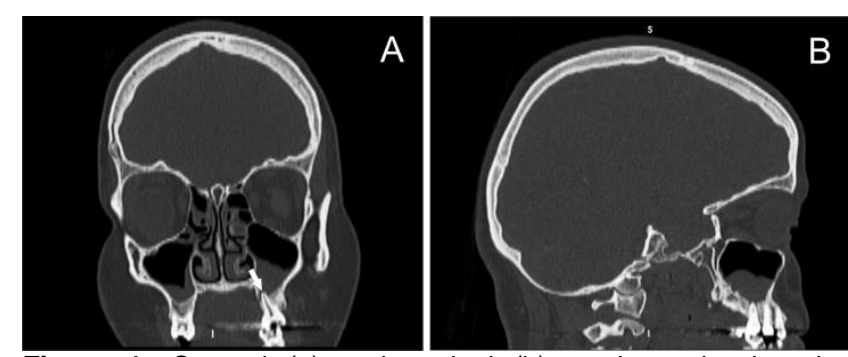

Figure 1: Coronal (a) and sagittal (b) sections showing the bilateral isodense area in the maxillary sinus regions. A-B) The proximity of the left maxillary sinus to the apex of tooth 26 is highlighted.

The dental consultation indicated a diffusion of the sinus infection to the dental tissues, requiring an emergency procedure due to diffuse facial cellulitis and edema associated with tooth 26. During an extraoral physical examination with the dental surgeon, the presence of facial cellulitis at the level of the left maxillary sinus was noticed. An intraoral physical examination indicated that tooth 26 presented a small restoration in composite resin, without clinical signs of recurrent caries. An abscess in the buccal oral mucosa relative to the apical region of the tooth 26 was verified. The tooth was isolated with cotton rolls to perform pulp sensitivity tests. A cold spray (EndoFrost ${ }^{\circledR}$, Coltene-Whaledent, Langenau, Germany) on cotton was positioned on the middle third of the buccal surface of the tooth, which showed no response to the stimulus. Warm Gutta-percha (Dentsply Maillefer, Ballaigues, Switzerland) was also used in the middle third of the vestibular surface as a thermal test, which also showed no response to the stimulus. Thus, the lack of response to thermal stimuli was indicative of absence of pulp vitality. In view of the observed condition, a periapical orthoradial radiograph was performed (Figure 2A), where the absence of communication of the pulp chamber with the restoration or contact of the pulp with the external environment was observed. Thus, the patient was diagnosed with an acute apical dentoalveolar abscess of sinus origin.

The tooth was anesthetized with $3.6 \mathrm{~mL}$ of $2 \%$ lidocaine containing 1:100,000 epinephrine. After disinfection and placement of a rubber barrier, an access cavity was created using a sterile diamond drill bit. After the pulp chamber was accessed, abundant irrigation was performed with $5 \mathrm{~mL}$ of $2.5 \%$ sodium hypochlorite $(\mathrm{NaOCl})$ and the channel was continuously flooded with this 
solution. The initial exploration of the canals was performed with endodontic files \# $15 \mathrm{~K}$ (Dentsply Maillefer, Ballaigues, Switzerland) for initial drainage and, in later sessions, the chemicalmechanical preparation of the root canals was finalized with the aid of ProTaper $U \AA$ files (Dentsply Maillefer, Ballaigues, Switzerland). The channels were filled with F2 gutta-percha cones (Dentsply Maillefer, Ballaigues, Switzerland), using AH Plus Sealer cement (Dentsply, DeTrey, Konstanz, Germany) for adhesion and the hot condensation technique with Gutta-Condensor \# 50 (Dentsply, Maillefer) was applied. After filling, a composite-resin restoration was performed, with subsequent occlusion adjustment (Figure 2B). Seven days after the canal was finished, facial edema and painful symptoms were reversed.
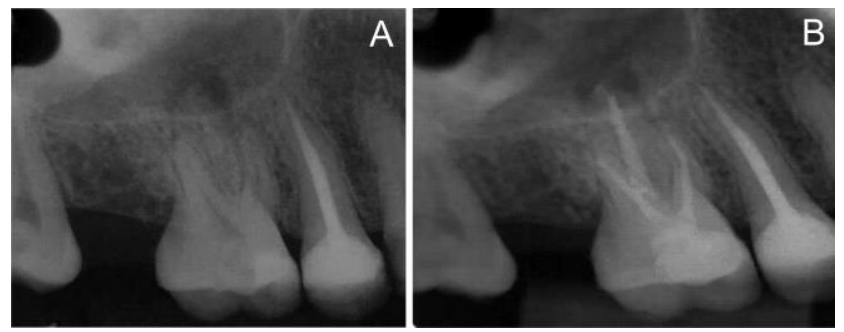

Figure 2: Initial radiographic appearance, where radiographic absence of communication of the restorative material with the pulp chamber is observed. In addition, thickening of the periodontal ligament and radiolucent area associated with the root apex and its intimate relationship with the maxillary sinus floor $(A)$ radiographic treatment after endodontic treatment (B).

After 30 days, a sinus tomography was performed, indicating significant improvement in the infectious process (Figures $3 A-B$ ). At the time, the otorhinolaryngologist prescribed montelukast sodium (10 mg, oral, once daily for 60 days) and mometasone furoate $(50 \mathrm{mcg}, 2$ atomizations, once a day for 60 days. After 6 months, the patient showed clinical improvement.

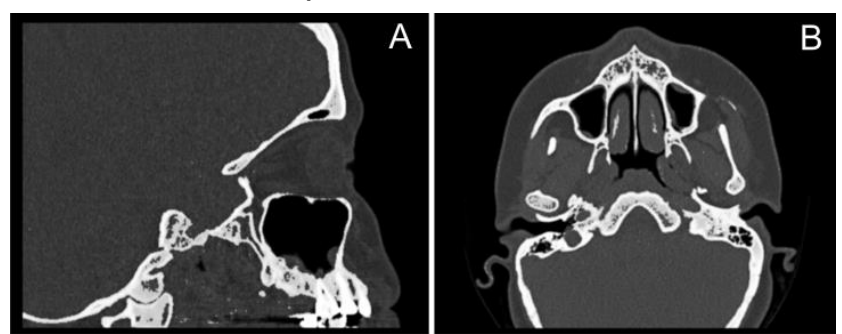

Figure 3: Sagittal (a) and axial (b) sections evidencing regression of the infected area 30 days after treatment.

DISCUSSION

Chronic rhinosinusitis (CRS) is characterized as a persistent inflammation of the nasal and sinusal mucosa, and knowledge concerning its pathophysiology has greatly increased in the last two decades ${ }^{13,14}$. However, its exact etiology has not yet been fully elucidated. In this context, several microorganisms and environmental factors have been implicated in its development ${ }^{13}$.

Few studies have been carried out with the aim of isolating and identifying the microbiota associated with $\mathrm{CRS}^{13,14}$. However, it is known that Staphylococcus are the most common microorganisms isolated from sinus cavities in patients with this condition ${ }^{13}$.

After evaluation of the microbiota present in patients with CRS, Mahdavinia et al. ${ }^{14}$ identified that lipopolysaccharide (LPS) synthesis proteins and bacterial invasion in epithelial cells were significantly higher in patients presenting CRS. Historically, LPS are known as endotoxins that make up part of the cell wall of Gram-negative bacteria. These endotoxins are released during multiplication, bacterial growth and bacterial disintegration after death, and their release is considered one of the factors associated with the development of acute inflammatory periapical disease ${ }^{15}$.

Due to the intimate anatomic relationship of the roots of the posterior teeth with the floor of the maxillary sinus, diffuse pain in the posterior region of the maxilla can be a diagnostic challenge for dental surgeons ${ }^{1,3}$. According to Lee and Lee $^{8}$, most odontogenic sinusitis present unilateral symptoms. However, for Bell et al. $^{16}$, there is no sign or symptom that differentiates sinusitis from acute dental pain. Thus, diagnosis is only achieved based on a combination of the patient's signs and symptoms with imaging findings.

According to Maillet et al. ${ }^{1}$, generalized thickening of the sinus mucosa may be involved with either allergic or infectious etiology diseases involving the upper respiratory tract or odontogenic causes. When performing an imaging evaluation of sinus mucosa thickening in 400 patients, Nascimento et al. $^{2}$ identified that generalized and unilateral thickening were the most frequent, the former associated with periodontal bone loss, and the latter with periapical lesions. The case reported herein comprised bilateral thickening, which emphasizes its non-odontogenic origin, since there was no clinical association with periodontal disease.

In healthy conditions, the dental pulp and apical periodontium are sterile. However, these structures may become infected and lead to apical dentoalveolar abscesses, due to deep or recurrent caries, dental trauma, direct contact of the root canals with deep periodontal pockets or endodontic infections ${ }^{17,18}$. Thus, considerations related to the etiology of acute apical dentoalveolar abscess in the case reported herein are difficult to establish, due to the fact that there was no clinical or radiographic evidence of deep or recurrent caries, dental trauma or associated periodontal pockets. According to Nair ${ }^{15}$, after pulp necrosis, the 
microorganisms present in the site tend to invade the periapical region, generating an inflammatory response in the periapical tissues, characterized by hyperemia, vascular congestion, periodontal ligament edema and neutrophil extravasation, the latter being attracted, mainly, by LPS.

According to Otavianni et al. ${ }^{19}$, the main symptoms associated with apical dentoalveolar abscess are pain, heat, redness, tumor and loss of function, usually adjacent to the teeth. The spread of acute dentoalveolar abscesses may result in odontogenic infections and, eventually, sepsis. However, the vast majority of cases respond to surgical treatment with pus drainage and root canal disinfection. Antibiotic therapy is indicated in case of systemic involvement, including signs and symptoms such as fever, tachycardia, regional lymphadenopathy or facial edema and trismus. In the case report herein, surgery was not necessary, since infection was controlled through dental access, with root canal disinfection and drainage of the purulent contents, associated with systemic antibiotic therapy.

Studies associating dissemination of odontogenic infections to the sinus region are common in the literature ${ }^{1-3}$. However, reports associating sinus infections to the dental region have not been reported. According to Hibi and Amakusa $^{20}$, intracranial infections of sinus origin have been reported and associated with the vascular support present in the region as the infection driving force. Similarly, it is believed that the vascular support present in the sinus region after the rhinoscopy is involved in the infection spread to the periapical region, leading to the development of the acute apical dentoalveolar abscess.

\section{FINAL CONSIDERATIONS}

Endodontic infections with repercussions in the sinus region have been widely debated in scientific circles. However, sinus infections with repercussions within the root canal system are uncommon. Considering the rarity of the case, it becomes of great importance to understand the clinical, radiographic and possible protocols for care, through a joint action of the dental surgeon and the otorhinolaryngologist. In addition, future studies that prospectively accompany patients with sinusopathies and association of teeth with the maxillary sinuses should be carried out, in order to evaluate pathology development in these regions.

\section{REFERENCES}

1. Maillet M, Bowles WR, McClanahan SL, John MT, Ahmad M. Cone-beam computed tomography evaluation of maxillary sinusitis. $J$ Endod. 2011;37(6):753-57.

2. Nascimento $E H$, Pontual ML, Pontual AA, Freitas DQ, Perez DE, Ramos-Perez FM. Association between Odontogenic Conditions and Maxillary Sinus Disease: A Study Using Cone-beam Computed Tomography. J Endod. 2016;42(10):1509-15.

3. Nunes CA, Guedes OA, Alencar AH, Peters $\mathrm{OA}$, Estrela CR, Estrela C. Evaluation of Periapical Lesions and Their Association with Maxillary Sinus Abnormalities on Cone-beam Computed Tomographic Images. J Endod. 2016;42(1):42-6.

4. Drumond JP, Allegro BB, Novo NF, de Miranda SL, Sendyk WR. Evaluation of the Prevalence of Maxillary Sinuses Abnormalities through Spiral Computed Tomography (CT). Int Arch Otorhinolaryngol. 2017;21(2):126-33.

5. Lana JP, Carneiro PM, Machado Vde C, de Souza PE, Manzi FR, Horta MC. Anatomic variations and lesions of the maxillary sinus detected in cone beam computed tomography for dental implants. Clin Oral Implants Res. 2012;23(12):1398-403.

6. Mehra $\mathrm{P}$, Murad $\mathrm{H}$. Maxillary sinus disease of odontogenic origin. Otolaryngol Clin North Am. 2004;37(2):347-64.

7. Cymerman JJ, Cymerman DH, O'Dwyer RS. Evaluation of odontogenic maxillary sinusitis using cone-beam computed tomography: three case reports. J Endod. 2011;37(10):1465-69.

8. Lee KC, Lee SJ. Clinical features and treatments of odontogenic sinusitis. Yonsei Med J. 2010;51(6):932-37.

9. Guerra-Pereira I, Vaz $P$, Faria-Almeida $R$, Braga AC, Felino A. CT maxillary sinus evaluation - a retrospective cohort study. Med Oral Patol Oral Cir Bucal. 2015;20(4):e419-26.

10. Brook I. Sinusitis of odontogenic origin. Otolaryngol Head Neck Surg. 2006; 135(3):349-55.

11. Drago L, Vassena C, Saibene AM, Del Fabbro M, Felisati G. A case of coinfection in a chronic maxillary sinusitis of odontogenic origin: identification of Dialister pneumosintes. J Endod. 2013;39(8):1084-87.

12. Kim JW, Cho KM, Park SH, Park SR, Lee SS, Lee SK. Chronic maxillary sinusitis caused by root canal overfilling of Calcipex II. Restor Dent Endod. 2014;39(1):63-7.

13. Karunasagar A, Garag SS, Appannavar SB, Kulkarni RD, Naik AS. Bacterial Biofilms in Chronic Rhinosinusitis and Their Implications for Clinical Management. Indian J Otolaryngol Head Neck Surg. 2018;70(1):43-8.

14. Mahdavinia M, Engen PA, LoSavio PS, Naqib A, Khan RJ, Tobin MC et al.The nasal microbiome in patients with chronic rhinosinusitis: Analyzing the effects of atopy and bacterial functional pathways in 111 
patients. J Allergy Clin Immunol. 2018;142(1):287-90.e4.

15. Nair PN. Pathogenesis of apical periodontitis and the causes of endodontic failures. Crit Rev Oral Biol Med. 2004;15(6):348-81.

16. Bell GW, Joshi BB, Macleod RI. Maxillary sinus disease: diagnosis and treatment. $\mathrm{Br}$ Dent $\mathrm{J}$. 2011;210(3):113-18.

17. Chavez de Paz LE. Redefining the persistent infection in root canals: possible role of biofilm communities. J Endod. 2007;33(6):652-62.

18. Larsen T, Fiehn NE. Dental biofilm infections an update. APMIS. 2017;125(4):376-84.

19. Ottaviani G, Costantinides F, Perinetti G, Luzzati R, Contardo L, Visintini $E$ et al. Epidemiology and variables involved in dental abscess: survey of dental emergency unit in Trieste. Oral Dis. 2014;20(5):499-504.

20. Hibi A, Amakusa Y. Intracranial subdural abscess with polymicrobial infections due to frontal sinusitis in an adolescent: lifethreatening complication of a common disease. Clin Case Rep. 2018;6(3):516-21.

\section{CONFLICTS OF INTERESTS}

The authors declare no conflicts of interests.

\section{CORRESPONDING AUTHOR}

\section{Hellen Bandeira de Pontes Santos}

Rua Dr. Antônio Palitot, ํ151, Ap 206 - Bancários 58051-780, João Pessoa - PB, Brasil

E-mail: hellenbps@hotmail.com 